\title{
MINERAL RESOURCE POTENTIAL OF THE WESTERN CHICHAGOF AND YAKOBI ISLANDS WILDERNESS STUDY AREA, SOUTHEASTERN ALASKA SUMMARY REPORT
}

\author{
By \\ Bruce R. Johnson, U.S. Geological Survey \\ and \\ Arthur L. Kimball and Jan C. Still, U.S. Bureau of Mines
}

Studies Related to Wilderness

In accordance with the provisions of the Wilderness Act (Public Law 88-577, September 3, 1964) and the Joint Conference Report on Senate Bill 4, 88th Congress, the U.S. Geological Survey and the U.S. Bureau of Mines have been conducting mineral surveys of the wilderness and primitive areas. Areas officially designated as "wilderness," "wild," or "canoe" when the act was passed were incorporated into the National Wilderness Preservation system and some of them are presently being studied. The act provides that the areas under consideration for wilderness designation should be studied for suitability for incorporation into the Wilderness System. The mineral surveys constitute one aspect of the suitability studies. The act directs that the results of such surveys are to be made available to the public and be submitted to the President and the Congress. This report discusses the results of a mineral survey of the Western Chichagof and Yakobi Islands Wilderness Study Area, Tongass National Forest, Alaska. About 65 percent of the study area was established as a wilderness on December 2, 1980, under the Alaska National Interest Lands Conservation Act (P.L. 96-487).

\section{MINERAL RESOURCE POTENTIAL SUMMARY STATEMENT}

The mineral resource potential of western Chichagof and Yakobi Islands, southeastern Alaska, has been assessed on the basis of geological and geochemical studies and examination of geochemical anomalies, known claims, prospects, and mines.

Four areas of high mineral potential and five areas of moderate mineral potential have been delineated on the basis of past production, claim and prospect density, known resources, deposit-type similarities, and geochemical anomalies. Areas with high mineral resource potential are:

1. Bohemia Basin area-Measured and inferred reserves total to 20.1 million tons containing 0.31 percent nickel, 0.18 percent copper, and 0.04 percent cobalt.

2. Mirror Harbor area-This area has smaller tonnage but similar grade to Bohemia Basin, and a nearby inferred reserve of 8,000 tons containing 1.57 percent nickel, 0.88 percent copper, and some cobalt.

3. Apex-El Nido area-This area has produced $17,000 \mathrm{oz}$ of gold and $2,400 \mathrm{oz}$ of silver and may have reserves of 25,000 oz of gold.

4. Doolth Mountain area-Past production has been 795,000 oz of gold and $233,000 \mathrm{oz}$ of silver, and the area has inferred reserves and inferred marginal reserves of about 316,000 oz of gold and 88,000 oz of silver. Identified and undiscovered resources are probably about equal to past production.

Areas of moderate potential for development of mineral deposits are:

A. Lisianski gold area-gold, silver, and tungsten.

B. Squid Bay-Lost Cove area-nickel, copper, and cobalt.

C. Mt. Baker copper area-copper.

D. West Coast gold area-gold and silver.

E. Slocum Arm molybdenum area-molybdenum.

Gold and silver were produced at several mines from 1906 through the early 1940 's from tabular ore bodies occurring in fault-controlled quartz fissure veins. Nickel-copper-cobalt magmatic segregation deposits in noritic Tertiary(?) intrusives were discovered at Mirror Harbor in 1911 and at Bohemia Basin in 1920. These deposits are presently being explored.

\section{INTRODUCTION}

Western Chichagof and Yakobi Islands are part of the Alexander Archipelago of southeastern Alaska. The study area is within the Tongass National Forest and is bounded on the northeast by a linear topographic low that includes Hoonah Sound and Lisianski Inlet and that nearly separates eastern Chichagof Island from western Chichagof Island. The study area is bounded on the southeast by Peril Strait, on the northwest by Cross Sound, and on the southwest by the Pacific Ocean. The area is approximately $60 \mathrm{mi}$ long and 20 


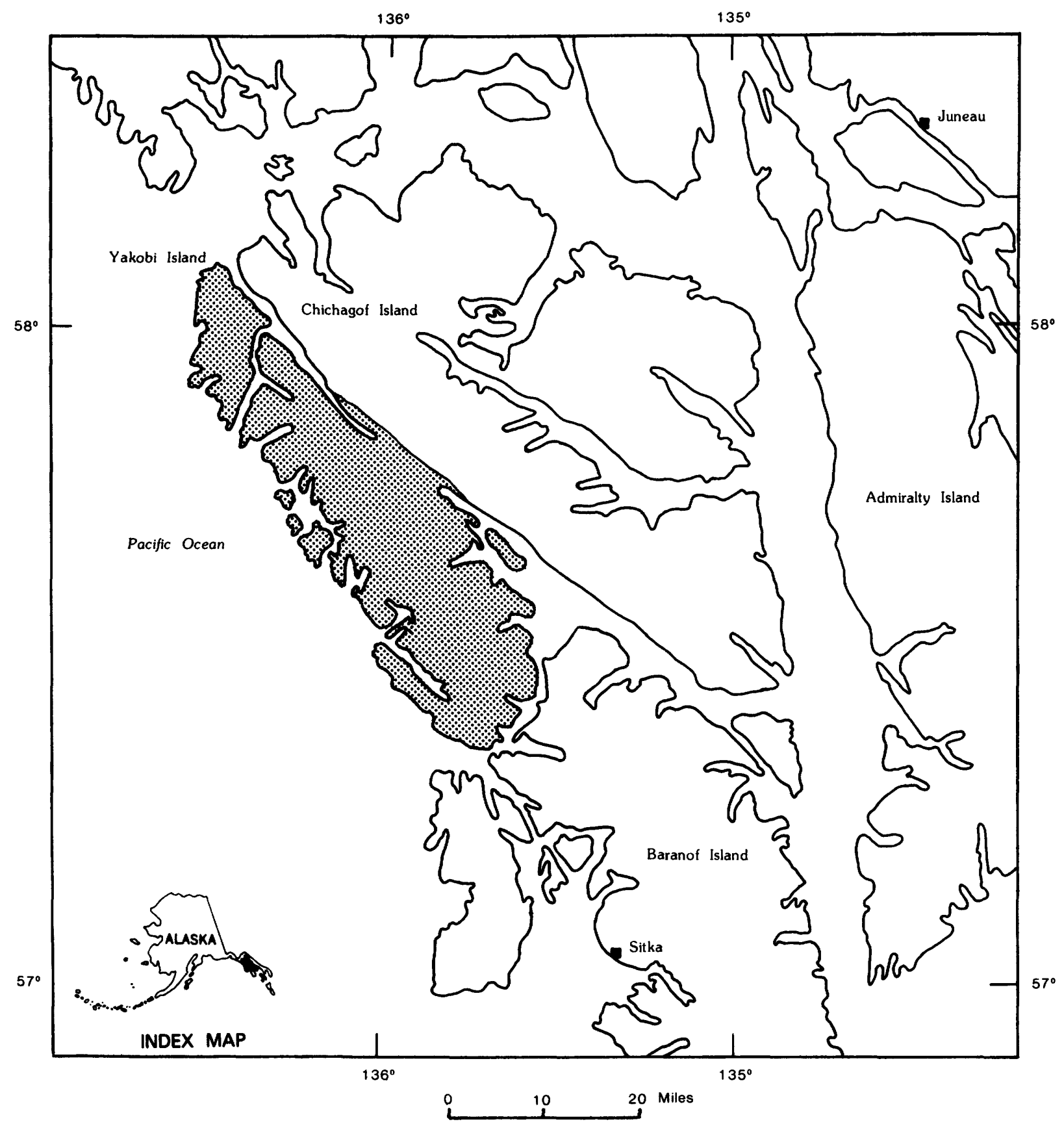

Figure 1.--Map showing the location of the Western Chichagof and Yakobi Islands Wilderness Study Area (indicated by stipple pattern). 
mi wide at the ridest point, and has an area of 405,000 acres or $633 \mathrm{mi}^{2}$ (fig. 1).

Topography is moderately rugged; high peaks and ridges at about $3,000 \mathrm{ft}$ elevation are separated by river valleys and lakes at near sea level elevations. The southwestern coastline is particularly irregular, consisting of myriad small islands, peninsulas, fiords, and reefs. The weather is typically maritime with temperature extremes moderated by the ocean. Low clouds, fog, and light rain or snow are typical at sea level most of the year; the ground is snow covered most of the winter months. The many fiords and inlets allow easy access to the shoreline for small boats except along the outermost coastline which is exposed to the open ocean. Ridgetops are generally rounded and easily traversed on foot. Due to the high rainfall, vegetation is extremely dense between sea level and about 2,000 ft elevation. The fishing village of Pelican on Lisianski Inlet is adjacent to the study area. A three-mile-long mine access road on Yakobi Island has been established from the beach to Bohemia Basin. No other roads are currently in use. Several short logging roads in the southern part of the area are no longer maintained.

\section{GEOLOGIC SETTING}

The sedimentary and metamorphic rocks of the Western Chichagof and Yakobi Islands Study Area can be divided into four roughly linear northwest-trending stratigraphic belts which are progressively younger toward the southwest (Johnson and Karl, 1982). The oldest rocks form a discontinuous belt, along Hoonah Sound and Lisianski Inlet, of sedimentary and volcanic rocks metamorphosed to medium to high grade. Paleozoic(?) hornfels, schist, gneiss, and marble are found in the northeastern part of this belt, and Mesozoic and (or) Paleozoic(?) amphibolite, amphibole gneiss, metavolcanic rock, volcaniclastic metasedimentary rock, and siliceous metasedimentary rocks are found in the southwestern part. The second belt of rocks, to the southwest, is composed of the Triassic(?) Goon Dip Greenstone and Whitestripe Marble. These two eastern belts have been intruded by Jurassic or Cretaceous diorite, quartz diorite, and tonalite plutons that exhibit a general northwest foliation.

A major fault that has been correlated with the Border Ranges fault to the northwest in south-central Alaska (Decker and Johnson, 1981) forms the boundary between the belts described above and the two younger belts to the southwest. This fault, representing a Late Cretaceous or early Tertiary subduction zone (MacKevett and Plafker, 1974; Plafker and others, 1976; Decker and Johnson, 1981), juxtaposes rocks of the Cretaceous and Cretaceous(?) Kelp Bay Group, which constitute the third belt, against the Triassic(?) greenstone and marble.

The Kelp Bay Group consists of a complex assemblage of Cretaceous metasedimentary and metavolcanic rocks including greenschist, phyllite, greenstone, marble, chert, graywacke, metatuff, and argillite. Typically, these units are composed of highly deformed, generally irregular, fault-bounded blocks. The fourth and youngest belt, southwest of the Kelp Bay Group and in fault contact with it, is composed of sandstone, siltstone, mudstone, and massive graywacke of the Cretaceous Sitka Graywacke. This belt exhibits the effects of a very weak regional metamorphism.
All of the belts have been intruded by Tertiary(?) plutonic rocks following movement on the Border Ranges fault. These intrusives are dominantly equidimensional stocks composed of nonfoliated tonalite and quartz diorite; however, they also include lesser amounts of granite, granodiorite, diorite, and gabbronorite. Thermal metamorphic aureoles as high as hornblende hornfels facies surround many of these plutons.

\section{MINING AND EXPLORATION ACTIVTTY}

The first mining claim in the study area was staked about 1867 for precious metals. The Chichagoff and Hirst-Chichagof deposits at Doolth Mountain were discovered in 1905 . The Chichagoff mine, initially financed on high-grade gold ore float, operated from 1906-1942 while the Hirst-Chichagof mine operated from 1922-1943. They jointly produced $793,000 \mathrm{oz}$ of gold and $233,000 \mathrm{oz}$ of silver from over 740,000 tons of ore. The Apex and El Nido mines, located between Lisianski Inlet and Stag Bay, and discovered in 1919 and 1920, respectively, produced nearly 17,000 oz of gold and 2,400 oz of silver from 1924-1939. Eight other mines in the study area produced from a few to 1,450 oz of gold and small amounts of silver.

Deposits of nickel-copper-cobalt were discovered at Mirror Harbor on the west coast of Chichagof Island in 1911, and at Bohemia Basin on Yakobi Island in 1920. During World War II, the U.S. Bureau of Mines, under the Strategic Minerals Program, examined the Bohemia Basin and Mirror Harbor occurrences and completed about 5,000 ft of diamond drilling (Kennedy and Walton, 1946; East and others, 1948; and Traver, 1948). During the 1950's, International Nickel Company explored these occurrences with $16,000 \mathrm{ft}$ of diamond drilling. From 1972 until the present, Inspiration Development Company has completed 29,000 ft of diamond drilling and has estimated that two deposits in the Bohemia Basin area contain a total of 20 million tons of rock averaging 0.18 percent copper, 0.31 percent nickel, and 0.04 percent cobalt. A third nearby deposit, incompletely drilled, is estimated to contain 4 million tons of mineralized rock (Inspiration Development Company press release, dated April 3, 1978).

A total of 3,336 lode claims, 36 placer claims, 41 mill sites, and 6 tunnel sites have been recorded in the study area. Of this number, 61 lode claims, 1 placer claim, and 4 mill sites have been patented. At the present time, 516 lode claims, 3 placer claims, and 3 mill sites have been recorded with the U.S. Bureau of Land Management.

\section{GEOLOGY AND GEOCHIMISTRY OF MINERAL RESOURCES}

\section{Gold Resources}

Mining activity within the study area began with the discovery of gold in 1905. Reports by Knopf (1912) and Overbeck (1919) describe the early development of the district and represent the first descriptions of the geologic setting of the major gold deposits. Reports by Reed and Coats (1941) and Rossman (1959) represent the most detailed descriptions of the peak mining activity and the geology of the gold 
occurrences on western Chichagof Island. Because none of the underground workings were examined by U.S. Geological Survey geologists during this study, the following descriptions are based on these earlier reports and surface examinations of this study.

Gold occurrences along the west coast of Chichagof Island, which includes nearly all of the production in the district, are found in weakly metamorphosed sedimentary and volcanic host rocks of the Kelp Bay Group and the structurally overlying Sitka Graywacke. These units generally strike northwest and dip steeply southwest. Sparse sedimentary features show tops to the northeast, indicating that the beds are generally overturned (Johnson and Karl, 1982). The host rocks are cut by numerous strike-slip and thrust(?) faults, which, in the vicinity of the mines, trend more northerly and dip more steeply than the beds. Mineralization commonly occurs along the faults.

A smaller number of gold occurrences, including the Apex-El Nido mine, occur chiefly in mafic plutonic rocks within the belt of Mesozoic and (or) Paleozoic(?) metamorphic rocks and are usually localized along northeast-striking faults and fractures. The Apex mine is situated within a small block of amphibolite country rock contained in a large, foliated, diorite pluton, and the El Nido is within an adjacent part of the pluton.

Both the older rocks of the northeastern belts and the Kelp Bay Group and younger rocks to the southwest are cut by small, felsic to intermediate stocks and dikes. The dikes in particular, which are believed to be related to Tertiary(?) plutonism (Rossman, 195\%; Loney and others, 1975), tend to be most abundant near localities of known mineralization. Gold usually occurs in quartz fissure veins in or near fault zones. Many of the ore bodies occur near bends in the fault surfaces or at intersections of the main faults and lesser splits. The ore bodies tend to be tabular, dip steeply, and are commonly a few feet thick and a few hundred feet long.

The mineralogy of the gold-bearing veins is relatively constant throughout the study area. The quartz veins carry from 0.5 to 3 percent pyrite, arsenopyrite, galena, sphalerite, chalcopyrite, gold, and locally tetrahedrite and scheelite. The similarity of structural setting, morphology, and proximity to Tertiary(?) dikes and the dissimilarity of some of the host rocks all indicate a similarity of source, which is not directly related to the immediate host rock. The source was most likely related to Tertiary(?) plutonism with the mineralizing fluids being localized by existing faults and fractures (Loney and others, 1975).

\section{Nickel-Copper-Cobalt Resources}

Nickel-copper-cobalt mineralization was discovered at Mirror Harbor in 1911 and at Bohemia Basin in 1920. These deposits have attracted considerable attention although no ore has been shipped. The geologic setting of the deposits was described in detail by Pecora (1942) and Reed and Dorr (1942). Since 1972 the properties have been controlled by the Inspiration Development Company, which has done extensive exploratory work and has announced reserves described under the section "Principal Mining Areas" below.
The nickel-copper-cobalt deposits occur as magmatic segregations in noritic and gabbronoritic facies of composite Tertiary(?) stocks that are generally potassium-poor and vary widely from tonalite to norite. The stocks intrude Cretaceous metavolcanic and metasedimentary rocks of the Kelp Bay Group and turbidites of the Sitka Graywacke. Contact metamorphic halos surround the stocks. The mineralogy of the ore bodies consists generally of pentlandite, chalcopyrite, and pyrrhotite in either massive or disseminated bodies. The massive sulfide bodies are podlike, small, and difficult to explore or delineate without extensive drilling.

\section{Geochemical Anomalies}

As part of this mineral resource assessment, stream sediment, panned concentrate from stream sediment, water, and bedrock were sampled and analyzed in an attempt to define areas of anomalous metal concentration. Individual element anomaly maps were generated and the results combined to define geochemically anomalous, areas (Johnson and Elliott, in press). The important anomalous areas, along with the elements which are anomalous in each, are shown on the accompanying map.

Some of the anomalous areas can be easily related to known mineralization. All areas designated as having high mineral potential are also areas of anomalous geochemical samples. Other anomalous areas include zones of known mineralization, but are much larger than the known mineralization. The remaining anomalous areas do not correlate with known mineralization. These areas range widely in size and geochemical intensity and in some places cross formation and terrane boundaries.

Anomalous areas not corresponding to known mineralization may indicate buried or otherwise undetected mineralization and may provide targets for future exploration. However, these areas may also be a result of analytical and sampling variance and, if so, provide little information about mineralization.

Although much of the area anomalous in copper is underlain by metavolcanic rock, bedrock composition does not seem to correlate well with copper content. Areas that are primarily anomalous in nickel, cobalt, chromium, and copper tend to be localized around mafic Tertiary(?) plutonic rocks and may be indicators of nickel-copper-cobalt mineralization similar to known mineralization. Other areas, which are mainly anomalous in copper, lead, zinc, molybdenum, silver, and gold, tend to be localized near major faults.

\section{PRINCIPAL MINING AREAS}

The study area lies within the Sitka recording district and the Chichagof mining district. The descriptions that follow are divided into the following areas on the basis of mining and exploration activity and mineral resource potential:

1. West Coast gold area-A moderate mineral potential area that includes the Doolth Mountain high mineral potential area.

2. Lisianski gold area-A moderate mineral potential area that includes the Apex-El Nido high mineral potential area. 
3. Bohemia Basin-Mirror Harbor area-Includes the Bohemia Basin and Mirror Harbor high mineral potential areas as well as the Squid Bay-Lost Cove moderate mineral potential area.

4. Mt. Baker copper area-A moderate mineral potential area.

5. Slocum Arm molybdenum area-A moderate mineral potential area.

Detailed descriptions of the mineralization, mines, prospects, and occurrences within each area as well as details of the individual resource calculations are given in A. L. Kimball (unpub. data, 1982) and Still and Weir (1981). The resource and reserve classification used throughout this report is defined in a joint report by the U.S. Bureau of Mines and the U.S. Geological Survey (1980). Locations of areas having mineral resource potential are shown on figure 2 and the accompanying map.

\section{West Coast Gold Area}

The West Coast gold area is approximately $8 \mathrm{mi}$ wide by $28 \mathrm{mi}$ long. It is characterized by hydrothermal gold-quartz mineralization along northwesterly striking, steeply dipping shear zones within graywacke, schist, and marble. For this study, 40 significant gold prospects or mines were examined. There are about 1,200 mining claims recorded in the area. Almost all of the production and prospecting activity occurred from 1905 to 1943.

The center of mining activity and production within the West Coast gold area is at Doolth Mountain, an area of approximately 5 by $6 \mathrm{mi}$. It contains most of the above-mentioned 1,200 unpatented claims, 52 patented claims, and almost all of the inferred and hypothetical gold resources of the study area. Production from this area is 795,000 oz of gold and 233,000 oz of silver, and it contains the following inactive mines:

Chichagoff mine-The Chichagoff mine is located on Doolth Mountain along the Chichagof fault, which has a traceable strike length of at least $12 \mathrm{mi}$. The mine opened in 1905 and closed in 1942; recorded production was 660,000 oz of gold and 200,000 oz of silver from over 600,000 tons of ore. The mine and adjacent mineralized area is covered by 29 patented claims and ranks as the third largest lode-gold producer in Alaska.

The deposit consists of gold-bearing quartz veins along the northwest-striking and steeply southwestdipping Chichagof fault. The wall rock is graywacke. The tabular but irregular ore zones have a long dimension down the rake toward the south and a short dimension along strike. Ore zone widths to $15 \mathrm{ft}$, strike lengths to $1,000 \mathrm{ft}$, and vertical heights to 1,800 $\mathrm{ft}$ are known. One 14-ft-wide stope averaged $6 \mathrm{oz}$ of gold per ton, whereas the average tenor for the life of the mine $w$ as 1.10 oz per ton. Mining reached a depth of 2,700 ft below sea level, and underground workings explore the fault for $4,800 \mathrm{ft}$ in a horizontal direction and $4,300 \mathrm{ft}$ vertically. Twenty-three percent of the area explored by underground workings was mined. Almost all mine workings are currently inaccessible.

Inferred marginal reserves having a mining width ranging from 3 to $15 \mathrm{ft}$ are:

i. Big Croppings area of Chichagof fault-22 samples from 12 U.S. Bureau of Mines surface sample lines and old mine records indicate 80,000 tons at 0.25 oz of gold per ton $(20,000 \mathrm{oz}$ of gold) and $0.08 \mathrm{oz}$ of silver per ton $(6,400$ oz of silver) above the 60 ft-elevation main haulage level.

2. Unmined area explored by underground workingsOld mine records and geologic inference indicate 155,000 tons at $0.30 \mathrm{oz}$ of gold per ton $(46,500 \mathrm{oz}$ of gold) and $0.09 \mathrm{oz}$ of silver per ton $(13,950 \mathrm{oz}$ of silver) above the main haulage level; 308,000 tons at $0.30 \mathrm{oz}$ of gold per ton $(92,400 \mathrm{oz}$ of gold) and $0.09 \mathrm{oz}$ of silver per ton $(27,720 \mathrm{oz}$ of silver) below the main haulage level.

Indicated marginal reserves:

1. Chichagoff tailings-36 U.S. Bureau of Mines shelby-tube and shovel samples on 4 sample lines, old mine records, company drill data, and reserve calculations indicate 456,000 tons at $0.11 \mathrm{oz}$ of gold per ton (50,160 oz of gold) and $0.03 \mathrm{oz}$ of silver per ton (13,680 oz of silver).

Inferred subeconomic resources:

1. Golden Gate \#3-26 U.S. Bureau of Mines underground samples on 11 sample lines having a 3-ft mining width indicate 13,500 tons at $0.11 \mathrm{oz}$ of gold per ton $(1,485 \mathrm{oz}$ of gold) and $0.04 \mathrm{oz}$ of silver per ton ( $540 \mathrm{oz}$ of silver).

2. Chichagoff dump-38 U.S. Bureau of Mines surface samples in 4 lines (inadequate to estimate grade for whole dump) indicate approximately 300,000 tons having surface value of $0.04 \mathrm{oz}$ of gold per ton and $0.012 \mathrm{oz}$ of silver per ton.

Hypothetical resources:

Chichagoff claim area not explored or having had very limited exploration underground. Old mine records, geologic inference, and U.S. Bureau of Mines sampling of near-surface workings indicate 500,000 tons at $0.60 \mathrm{oz}$ of gold per ton $(300,000 \mathrm{oz}$ of gold) and $0.18 \mathrm{oz}$ of silver per ton $(90,000 \mathrm{oz}$ of silver).

Hirst-Chichagof Mine-This property is along the 8.5-mi-long Hirst fault, which is parallel to and approximately $0.8 \mathrm{mi}$ northeast of the Chichagof fault. The property was staked in 1905 and operated from 1922 to 1943 . The structure is explored along $5,000 \mathrm{ft}$ of strike, up to $2,200 \mathrm{ft}$ vertically, and mining reached a depth of $1,800 \mathrm{ft}$ below sea level. It produced 131,000 oz of gold and 33,000 oz of silver from over 140,000 tons of ore. Old records indicated that less than 10 percent of the area explored by underground workings was mined. Almost all of the old workings are currently inaccessible. The mine and adjacent mineralized area are partially covered by 12 patented claims. The deposit is similar to the Chichagoff Mine; the major exception is that a high-grade ore shoot was found 1,600 ft along a hanging wall split off the Hirst fault. At least 5,500 ft of strike length of the main fault in the vicinity of the underground workings was not explored.

Inferred reserves that have a mining width exceeding $3 \mathrm{ft}$ are:

1. Continuation of Kay ore shoot (mining halted in 1943). Old mine records and geologic inference indicate 80,000 tons at $1.00 \mathrm{oz}$ of gold per ton ( $80,000 \mathrm{oz}$ of gold) and $0.25 \mathrm{oz}$ of silver per ton (20,000 oz of silver).

Inferred marginal reserves:

1. Unmined area explored by underground workings (mining width 3-10 ft)-Old mine records, minor U.S. Bureau of Mines underground and surface samples, and geologic inference indicate 70,000 
tons at 0.25 oz of gold per ton $(17,500$ oz of gold) and $0.06 \mathrm{oz}$ of silver per ton $(4,200 \mathrm{oz}$ of silver).

2. Hirst tailings-11 U.S. Bureau of Mines shelbytube and shovel samples on 3 sample lines, old mine records, and an assumption that at least $\mathbf{5 0}$ percent of original mine tailings are located in or near the tidal zone where recovery is practical indicate 70,000 tons at $0.14 \mathrm{oz}$ of gold per ton $(9,800 \mathrm{oz}$ of gold) and $0.03 \mathrm{oz}$ of silver per ton $(2,100$ oz of silver).

Inferred subeconomic resources:

1. Hirst-Chichagof dump-13 U.S. Bureau of Mines surface samples in 2 lines (inadequate to estimate grade for whole dump) indicate approximately 70,000 tons having surface value of $0.04 \mathrm{oz}$ of gold per ton and $0.01 \mathrm{oz}$ of silver per ton.

Hypothetical resources:

1. Unexplored part of the Hirst fault in the mine area (Hirst-Chichagof 1938 claim area)-Old mine records and geologic inference indicate a possibility of 100,000 tons at $1.00 \mathrm{oz}$ of gold per ton $(100,000 \mathrm{oz}$ of gold) and $0.25 \mathrm{oz}$ of silver per ton (25,000 oz of silver).

Other mines located in the Doolth Mountain area are the Alaska Chichagof which produced $660 \mathrm{oz}$ of gold in 1936 and the Jumbo which produced an estimated 1,450 oz of gold in about 1909. Both consist of quartz fissure veins located on prominent fault zones parallel to the Chichagof fault, 2,800 ft and 3,200 ft, respectively, from it. Other gold-silver prospects on fault zones approximately parallel to the Chichagof fault are the McKallick Lode, American Gold Company, and Baney.

The most favorable mines and prospects north and south of the Doolth Mountain area, but within the West Coast gold area, are as follows:

Golden Hand Apex mine-This property was staked in 1921 along a northwest-striking, quartzbearing fault zone. Workings, mostly completed in the 1920 's, consist of a 150-ft-long sloughed trench, $140 \mathrm{ft}$ of crosscut, and $85 \mathrm{ft}$ of drift. Mine claims are presently active, and a small amount of high-grade ore was produced in 1979. A quartz vein exposed for $23 \mathrm{ft}$ in two trenches averaged $0.34 \mathrm{oz}$ of gold per ton (six sample lines) across a 3-ft mining width, whereas a representative sample across a $0.02-$ by $3-\mathrm{ft}$ highgrade zone in the footwall of the same vein assayed $187 \mathrm{oz}$ of gold per ton, and a single select sample assayed 489 oz of gold per ton.

Cobol mine-This property was staked in 1925 along gold-bearing quartz veins in a northerly striking fault zone. The claims are currently active. Workings include 2,150 ft of drifts; production is estimated at over 100 oz of gold. A 57-ft-long zone exposed underground averages 0.28 oz of gold per ton for a 3-ft mining width. A float sample below a reported $140-\mathrm{ft}-$ long high-grade zone, now covered by a landslide, assayed 8.74 oz of gold per ton.

Other prospects that have significant gold values in the West Coast gold area are the New Chichagof Mining Syndicate to the north and the Falcon Arm to the south.

\section{Lisianski Gold Area}

The Lisianski gold area is approximately $4 \mathrm{mi}$ wide by $15 \mathrm{mi}$ long. The area is characterized by goldquartz occurrences along shear zones in diorite, amphibolite, greenstone, and schist. The western boundary of the area is drawn to include gold prospects and reported occurrences in the vicinity of Stag Bay; the eastern boundary is Lisianski Inlet. The northern boundary includes the northernmost gold prospect having recorded production, on Yakobi Island near Miner Island, and the southern boundary includes the southernmost similar gold prospect on the northwest end of Mine Mountain. The area includes five properties that produced about $18,000 \mathrm{oz}$ of gold and 2,500 oz of silver and about 12 other localities at which gold occurrences have been reported. Excluding the Bohemia Basin parts, 330 claims have been recorded in the area.

On the basis of gold production, the most important part of the Lisianski gold area is the Apex-El Nido high mineral potential area, which contains 130 recorded claims.

Apex-El Nido mines-The Apex and El Nido goldbearing quartz veins were discovered in 1919 and 1920 , respectively, and produced about $17,000 \mathrm{oz}$ of gold and $2,400 \mathrm{oz}$ of silver in the periods 1924-28, 1934-35, and 1937-39. Currently, the area contains 41 unpatented lode and 3 placer claims, mostly on the northeast side of Apex Mountain.

The deposits consist of 1- to 4-ft-thick, steeply dipping, gold-bearing quartz veins emplaced in faults in diorite and amphibolite. Sporadically distributed scheelite also is found in the veins. The main Apex vein strikes northeast and dips about 50 , northwest; the El Nido vein strikes about N. 70, E. and dips 30, to 80 , southeast. Where worked, the two vein systems were separated by approximately $2,000 \mathrm{ft}$ of country rock.

Most of the gold production came from the Apex property. The condition of the underground workings in 1978-1979 was such that, although both El Nido levels were sampled, only one of four Apex levels was accessible and no stope in either mine was safe to enter. Eighty-five measured surface samples along a complex set of quartz veins over a strike length of 800 ft on the apparent up-dip projections of the Apex structure did not show consistent gold values nor reasonable correlation with a 1929 company sampling program. The 1929 company data (Holmes, 1941) indicate high gold values over a long strike length. Holmes (1941) implied that a reserve of 26,600 tons having an average grade of nearly $1 \mathrm{oz} /$ ton was present in 1941. Rossman (1959) stated that the ore reserves at the Apex mine are not large. Because of the lack of correlation of the surface samplings, inaccessibility of underground workings, and the complex character of the vein systems, it is not possible to calculate reserves for the Apex-El Nido properties on the basis of present information.

Recorded production in the Lisianski gold area north of the Apex-El Nido mines includes:

1. Bon Tara mine-Discovered in 1886 , gold-bearing quartz veins in shear zones in diorite rocks have been explored by open cuts and a 35-ft adit. The only recorded production has been $50 \mathrm{oz}$ of highgrade specimen ore.

2. Goldwin mine-Discovered in 1923, quartz veins as much as $2 \mathrm{ft}$ wide in diorite were explored by a 240-ft adit. Rossman (1959) reported an assay of 69 oz of gold per ton on a short section of pyritic vein. Three other nearby samples assay from a trace to $0.11 \mathrm{oz}$ of gold per ton. 


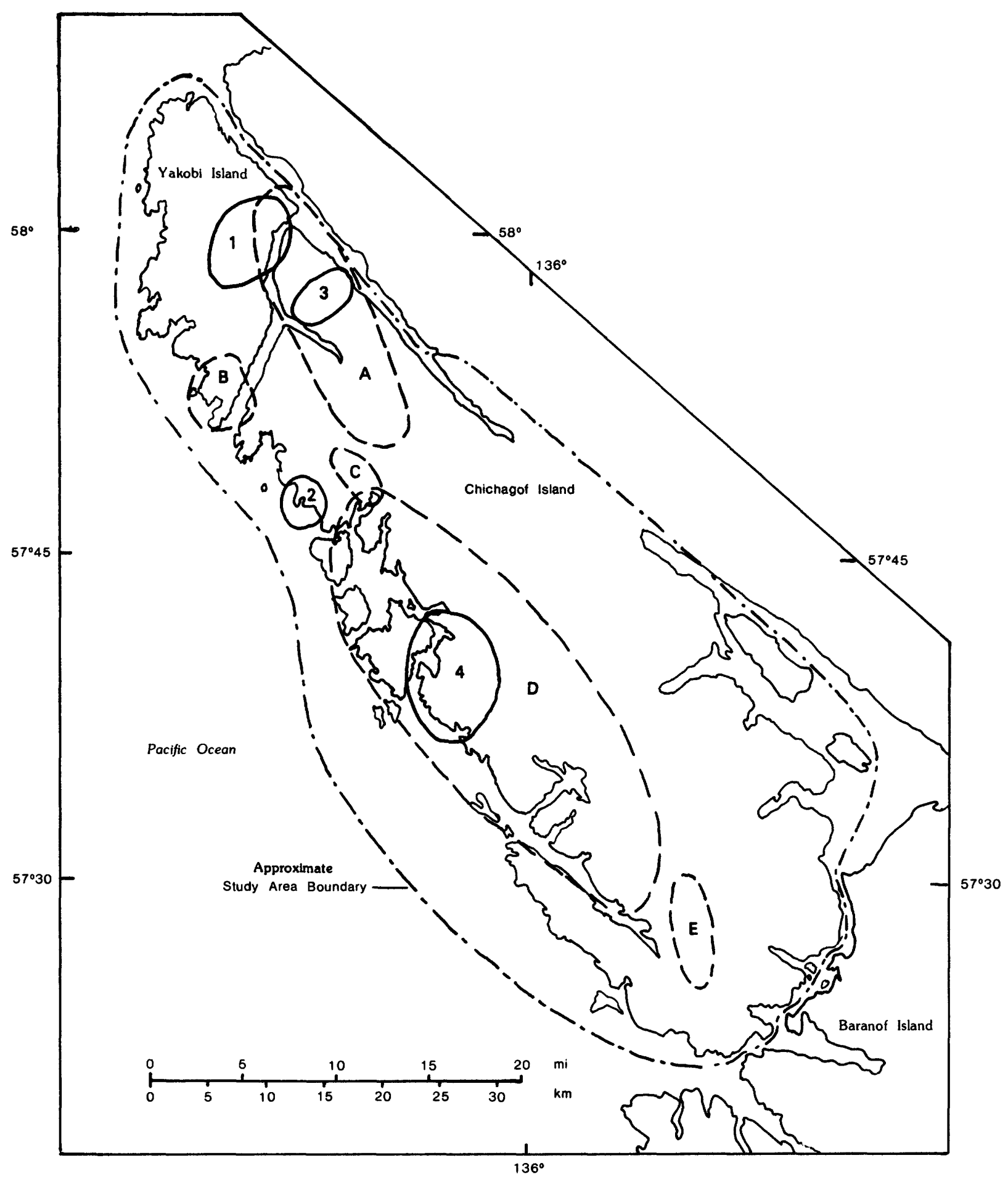

Figure 2.--Map of the Western Chichagof and Yakobi Islands Wilderness Study Area showing areas of high mineral resource potential (solid line), and areas of moderate mineral resource potential (dashed line). Areas labeled are: 1, Bohemia Basin; 2, Mirror Harbor; 3, Apex-E1 Nido; 4, Doolth Mountain; A, Lisianski; B, Squid Bay-Lost Cove; C, Mt. Baker; D, West Coast; E, Slocum Arm. 
The southern boundary of the Lisianski gold area includes:

1. Cobol-Mine Mountain mine-Discovered in 1921, gold-bearing quartz veins in diorite and greenstone were explored by $260 \mathrm{ft}$ of crosscuts and drifts; recorded production was 100-150 oz of gold. U.S. Bureau of Mines samples of a stoped area $70 \mathrm{ft}$ long, along a $0.2-$ to $1.2-\mathrm{ft}$-wide vein, yielded results of nil to $2.45 \mathrm{oz}$ of gold per ton; an unstoped area $120 \mathrm{ft}$ long, along a $0.05-$ to $0.7-\mathrm{ft}-$ wide vein yielded results of nil to $2.29 \mathrm{oz}$ of gold per ton.

\section{Bohemia Basin-Mirror Harbor Nickel-Copper-Cobalt Areas}

The Bohemia Basin-Mirror Harbor nickel-coppercobalt areas are on Yakobi Island and the northwestern part of Chichagof Island.

Bohemia Basin-This is the largest of the known nickel-copper-cobalt occurrences; 980 mining claims have been recorded since $1920 ; 265$ are unpatented active claims and 9 are patented claims. The mineralization occurs as magmatic segregations of sulfide phases in gabbro and gabbronorite.

Extensive surface exploration and more than $50,000 \mathrm{ft}$ of diamond drilling have partially delineated three mineralized bodies that range in shape from an elongate bowl and funnel-shaped body to tabularshaped bodies. The two largest bodies are reported to contain at least $20,100,000$ tons averaging 0.31 percent nickel, 0.18 percent copper, and 0.04 percent cobalt (Inspiration Development Company, press release dated April 3, 1978) in measured and inferred categories (Vance Thornsberry, Inspiration Development Company, oral commun., 1980). One of the known bodies for which reserves are calculated is not thoroughly delineated in the down-dip limits. The third body, which is not included in the tonnage figure, is incompletely delineated, but preliminary estimates by the owner show a "geologic" reserve of approximately 4 million tons of mineralized rock.

Mirror Harbor-Similar magmatic segregations are known in mafic rocks $15 \mathrm{mi}$ to the southeast on Chichagof Island near Mirror Harbor. These occurrences have been known since 1911, and 330 claims have been recorded; 114 claims are current. About 8,000 tons containing 1.57 percent nickel and 0.88 percent copper are reported by Kennedy and Walton (1946) in one ore body. Cobalt is present, but the average grade is unknown. A U.S. Bureau of Mines grab sample contained 0.07 percent cobalt. In another nearby body, Kennedy and Walton (1946) report several million tons of lower grade material. Exploration, including diamond drilling, has been conducted during the past several seasons in this area, and although tonnage estimates are not available, seven diamonddrill holes have intercepts of nickel, copper, and cobalt similar in grade to Bohemia Basin. They have been interpreted as defining a mineralized zone in a layered mafic deposit (Vance Thornsberry, Inspiration Development Company, oral commun., August 1980).

Squid Bay-Lost Cove Area-This area is about 8 mi south of Bohemia Basin on Yakobi Island and northwestern Chichagof Island. Host rocks at this locality are similar to the Mirror Harbor occurrences. About 50 claims have been recorded. U.S. Bureau of Mines samples from this area contain low copper values and minor nickel and cobalt. Additional claims have been recorded from 1917 to 1972 on other parts of Yakobi Island on similar mafic intrusive rocks.

\section{Mt. Baker Copper Area}

Ninety claims have been recorded in the $\mathrm{Mt}$. Baker copper area. The largest known concentration of copper is in a northwest-striking vertical zone in greenstone 350-400 ft long. Several trenches (now collapsed), a shallow shaft, and a crosscut have been opened. A trench at the southeastern end of the zone contains 2.0 percent copper across a $13-\mathrm{ft}$ width, and a shallow shaft at the northwest end of the zone contains 7.5 percent copper across a 2-ft width. Both ends also contain minor gold and silver. Several smaller pods containing copper minerals are exposed on the southeastern side of the mountain and carry lower copper assay values. They are approximately alined with the workings just described and suggest stratigraphic or structural control but do not suggest mineralogical continuity along the trend. Potential geophysical and geochemical exploration targets, which have been established in the immediate area by past exploration activity along with geochemical results and mineralized float, indicate a possible $2-$ to 3-mi extension of the main mineralized zone.

\section{Slocum Arm Molybdenum Area}

The Slocum Arm molybdenum area is $1.5 \mathrm{mi}$ east of Hidden Cove at the southern end of Slocum Arm. Twelve claims have been recorded of which 10 are currently active. Molybdenum mineralization occurs in small quartz veins, dikes, and country rock across an area $0.75 \mathrm{mi}$ wide by $1.5 \mathrm{mi}$ long near a dioritic intrusion.

\section{MINERAL RESOURCE POTENTIAL SUMMARY}

Areas of high and moderate mineral resource potential and geochemically anomalous areas are shown on the accompanying map. Areas of high mineral resource potential contain known economic mineralization or have high probability for such mineralization. Areas of moderate mineral resource potential are those where some conditions for economic mineralization have been met, but evidence of economic mineralization is less certain.

Four areas of high mineral resource potential have been identified in the study area (fig. 2). These areas and the criteria used for their designation are:

1. Bohemia Basin area (no. 1 on fig. 2)-Ni-Cu-Co

a. Measured and inferred reserves: 20.1 million tons at 0.31 percent nickel, 0.18 percent copper, and 0.04 percent cobalt.

b. Extensions into areas geologically similar to those of known mineralization.

c. Exploration activity.

d. Claim density.

2. Mirror Harbor area (no. 2 on fig. 2) $-\mathrm{Ni}-\mathrm{Cu}-\mathrm{Co}$

a. Inferred reserves: 8,000 tons at 1.57 percent nickel, 0.88 percent copper, some cobalt present. Reported larger tonnage of grade approximately equal to that of Bohemia Basin.

b. Claim density.

c. Exploration activity. 
3. Apex-El Nido area (no. 3 on fig. 2)-Au-Ag

a. Production: 17,000 oz of gold, $2,400 \mathrm{oz}$ of silver.

b. Unconfirmed reported reserves of $25,000 \mathrm{oz}$ of gold (Holmes, 1941).

4. Doolth Mountain area (no. 4 on fig. 2)-Au-Ag

$\begin{array}{ccc}\text { a. Production } & \text { Gold } & \text { Silver } \\ \text { a } & 795,000 \mathrm{oz} & 233,000 \mathrm{oz}\end{array}$

b. Resources

Inferred reserves $\quad 80,000 \mathrm{oz} \quad 20,000 \mathrm{oz}$

Indicated marginal

reserves

Inferred marginal

reserves

Inferred subeco-

nomic resources

Hypothetical

resources

c. Claim density.

d. Potential continuation of known gold-silver mineralization along prominent fault zones.

Five areas of moderate mineral resource potential for deposits of one or more of the following metals: gold, silver, nickel, copper, cobalt, tungsten, and molybdenum have been identified:

A. Lisianski gold area (A on fig. 2)-Au, Ag, W

B. Squid Bay-Lost Cove area (B on fig. 2)-Ni, $\mathrm{Cu}$, Co

C. Mt. Baker copper area (C on fig. 2)-Cu

D. West Coast gold area (D on fig. 2)-Au, Ag

E. Slocum Arm molybdenum area (E on fig. 2 )-Mo

These areas are discussed in more detail in a previous section titled "Principal Mining Areas." Some area boundaries were constructed by projecting known mineralization to areas of similar geology and structure. High claim density and position of important prospects were also important criteria for establishing boundaries.

\section{REFERENCES}

Decker, J. E., and Johnson, B. R., 1981, The nature and position of the Border Ranges fault on Chichagof Island, in Albert, N.R.D., and Hudson, Travis, eds., The U.S. Geological Survey in Alaska; Accomplishments during 1979: U.S. Geological Survey Circular 823-B, p. B102-B104.

East, J. H., Jr., Traver, W. M., Sanford, R. S., and Wright, W. S., 1948, Yakobi Island nickel deposit, Sitka mining district, Alaska: U.S. Bureau of Mines Report of Investigations $4182,28 \mathrm{p}$.

Holmes, G. L., 1941, Report on the Apex-El Nido Mine: U.S. Bureau of Mines unpublished report, available at U.S. Bureau of Mines Library, Juneau, Alaska, 20 p.

Johnson, B. R., and Elliott, G. S., (in press), Map showing the distribution and abundance of gold and silver in bedrock samples, West ChichagofYakobi Islands Wilderness Study Area, southeastern Alaska: U.S. Geological Survey Open-File Report 81-27C, scale 1:125,000.

(in press), Map showing the distribution and abundance of boron and beryllium in bedrock samples, West Chichagof-Yakobi Islands Wilderness Study Area, southeastern Alaska: U.S. Geological Survey Open-File Report 81-27D, scale $1: 125,000$. (in press), Map showing the distribution and abundance of copper in bedrock samples, West Chichagof-Yakobi Islands Wilderness Study Area, southeastern Alaska: U.S. Geological Survey Open-File Report 81-27E, scale $1: 125,000$.

(in press), Map showing the distribution and abundance of cobalt in bedrock samples, West Chichagof-Yakobi Islands Wilderness Study Area, southeastern Alaska: U.S. Geological Survey Open-File Report 81-27F, scale 1:125,000.

(in press), Map showing the distribution and abundance of molybdenum, tin, and vanadium in bedrock samples, West Chichagof-Yakobi Islands Wilderness Study Area, southeastern Alaska: U.S. Geological Survey Open-File Report 81-27G, scale 1:125,000.

(in press), Map showing the distribution and abundance of nickel and chromium in bedrock samples, West Chichagof-Yakobi Islands Wilderness Study Area, southeastern Alaska: U.S. Geological Survey Open-File Report 81-27H, scale $1: 125,000$.

(in press), Map showing the distribution and abundance of lead in bedrock samples, West Chichagof-Yakobi Islands Wilderness Study Area, southeastern Alaska: U.S. Geological Survey Open-File Report 81-27I, scale 1:125,000.

(in press), Map showing the distribution and abundance of scandium and yttrium in bedrock samples, West Chichagof-Yakobi Islands Wilderness Study Area, southeastern Alaska: U.S. Geological Survey Open-File Report 81-27J, scale $1: 125,000$.

(in press), Map showing the distribution and abundance of strontium and lanthanum in bedrock samples, West Chichagof-Yakobi Islands Wilderness Study Area, southeastern Alaska: U.S. Geological Survey Open-File Report 81-27K, scale $1: 125,000$.

(in press), Map showing the distribution and abundance of zinc in bedrock samples, West Chichagof-Yakobi Islands Wilderness Study Area, southeastern Alaska: U.S. Geological Survey Open-File Report 81-27L, scale 1:125,000.

Johnson, B. R., and Karl, S. M., 1982, Reconnaissance geologic map of the Western Chichagof and Yakobi Islands Wilderness Study Area, southeastern Alaska: U.S. Geological Survey Miscellaneous Field Studies Map MF-1476-A, scale $1: 125,000$.

Kennedy, G. C., and Walton, M. S., Jr., 1946, Nickel investigations in southeastern Alaska: U.S. Geological Survey Bulletin 947-C, p. C39-C64.

Knopf, Adolph, 1912, The Sitka mining district, Alaska: U.S. Geological Survey Bulletin 504, $32 \mathrm{p}$.

Loney, R. A., Brew, D. A., Muffler, L.J.P., and Pomeroy, J. S., 1975, Reconnaissance geology of Chichagof, Baranof, and Kruzof Islands, southeastern Alaska: U.S. Geological Survey Professional Paper 792, 105 p.

MacKevett, E. M., Jr., and Plafker, George, 1974, The Border Ranges fault in south-central Alaska: U.S. Geological Survey Journal of Research, v. 2, no. 3, p. 323-329. 
Overbeck, R. Mo, 1919, Geology and mineral resources of the west coast of Chichagof Island: U.S. Geological Survey Bulletin 692-B, p. 91-136.

Pecora, W. T., 1942, Nickel-copper deposits on the west coast of Chichagof Island, Alaska: U.S. Geological Survey Bulletin 936-I, p. I221-1243.

Plafker, George, Jones, D. L., Hudson, Travis, and Berg, H. C., 1976, The Border Ranges fault system in the Saint Elias Mountains and Alexander Archipelago, in Cobb, E. H., The United States Geological Survey in Alaska; Accomplishments during 1975: U.S. Geological Survey Circular 733, p. 14-16.

Reed, J. C., and Coats, R. R., 1941, Geology and ore deposits of the Chichagof mining district, Alaska: U.S. Geological Survey Bulletin 929, $148 \mathrm{p}$.
Reed, J. C., and Dorr, J.V.N., II, 1942, Nickel deposits of Bohemia Basin and vicinity, Yakobi Island, Alaska: U.S. Geological Survey Bulletin 931-F, p. F105-F138.

Rossman, D. L., 1959, Geology and ore deposits of northwestern Chichagof Island, Alaska: U.S. Geological Survey Bulletin 1058-E, p. E139-E216.

Still, J. C., and Weir, K. R., 1981, Mineral land assessment of the west portion of western Chichagof Island, southeastern Alaska: U.S. Bureau of Mines Open-File Report 89-81, $168 \mathrm{p}$.

Traver, W. M., Jr., 1948, Mirror Harbor nickel deposits, Chichagof Island, Alaska: U.S. Bureau of Mines Report of Investigations 4168, 13 p.

U.S. Bureau of Mines, and U.S. Geological Survey, 1980, Principles of a resource/reserve classification for minerals: U.S. Geological Survey Circular 831, 5 p. 